\title{
Absence of Fenfluramine-Induced Anorexia and Reduced c-fos Induction in the Hypothalamus and Central Amygdaloid Complex of Serotonin 1B Receptor Knock-Out Mice
}

\author{
José J. Lucas, ${ }^{1}$ Ai Yamamoto, ${ }^{1}$ Kimberly Scearce-Levie, ${ }^{1}$ Frédéric Saudou, ${ }^{2}$ and René Hen ${ }^{1}$ \\ ${ }^{1}$ Center for Neurobiology and Behavior, Columbia University, New York, New York 10032, and 2 Division of Neuroscience, \\ Children's Hospital, Department of Neurobiology, Harvard Medical School, Boston, Massachusetts 02115
}

Fenfluramine, a serotonin releaser and uptake inhibitor, has been widely prescribed as an appetite suppressant. Despite its popular clinical use, however, the precise neural pathways and specific 5-HT receptors that account for its anorectic effect have yet to be elucidated. To test the hypothesis that stimulation of $5-\mathrm{HT}_{1 \mathrm{~B}}$ receptors is required for the anorectic effect of fenfluramine, we assessed food intake in wild-type and $5-\mathrm{HT}_{1 \mathrm{~B}}$ knock-out mice. Next, to determine possible brain structures and pathways that may contribute to the $5-\mathrm{HT}_{1 \mathrm{~B}}-$ mediated effects of fenfluramine, we studied by immunohistochemistry the induction of the immediate early gene c-fos. Although the effect of fenfluramine on locomotion was indistinguishable between both wild-type and 5- $\mathrm{HT}_{1 \mathrm{~B}}$ knock-out mice, the anorectic effect of the drug was absent in only the knock-out mice. Furthermore, the induction of c-Fos immunoreactivity found in

Obesity and associated pathologies, including diabetes and cardiovascular disease, are serious health concerns in developed countries (Garrow, 1991; Kuczmarski et al., 1994). In recent years, there has been a substantial increase in both research and use of centrally acting appetite suppressants, which have been shown to facilitate weight loss and prevent weight regain in obese patients (Silverstone, 1992; Davis and Foulds, 1996). The most popular and widely prescribed of these drugs had been fenfluramine, a serotonin releaser and uptake inhibitor (Guy-Grand, 1995). Despite its popular clinical use, however, the precise neural pathways and specific 5-HT receptors that mediate its anorectic effect are not yet understood.

The diversity of 5-HT receptors and lack of specific antagonists have complicated attempts to elucidate the specific receptors involved in fenfluramine-induced hypophagia (Hoyer et al., 1994; Simansky, 1996). Studies with nonselective 5-HT antagonists have determined that the contributions of $5-\mathrm{HT}_{1 \mathrm{~A}}, 5-\mathrm{HT}_{2 \mathrm{~A}}$,

Received March 6, 1998; revised May 5, 1998; accepted May 7, 1998.

This work was supported by National Institute on Drug Abuse Grant DA09862 (R.H.), National Institute of Mental Health Grant MH48125-06 (R.H.), and a Brystol Myers Squibb Unrestricted Neuroscience Award (R.H.). J.J.L. is recipient of a fellowship from the Ministry of Science and Education of Spain. K.S.-L. is a recipient of a Howard Hughes Medical Institute predoctoral fellowship. We thank Dr. Arango for the computerized image analysis system facility and Drs. Brunner and Simansky for helpful discussion.

Drs. Lucas and Yamamoto contributed equally to this work.

Correspondence should be addressed to René Hen, Center for Neurobiology and Behavior, Columbia University, 722 West 168th Street, P.I. Annex 731, New York, NY 10032.

Dr. Lucas's present address: Centro Biologìa Molecular Severo Ochoa CBMSO/ CSIC, Universidad Autonoma Madrid, Canto Blanco, Madrid 28049, Spain.

Copyright (C) 1998 Society for Neuroscience $\quad 0270-6474 / 98 / 185537-08 \$ 05.00 / 0$ the paraventricular nucleus of the hypothalamus (PVN) of wildtype mice was substantially reduced in the knock-outs. Induction in the central amygdaloid nucleus (CeA) and in the bed nucleus of the stria terminalis (BNST), although robust in wildtype animals, was completely absent in knock-out animals. The mixed 5- $\mathrm{HT}_{1 \mathrm{~A} / 1 \mathrm{~B}}$ agonist RU24969 was able to mimic both the hypophagia and $\mathrm{c}$-fos induction elicited by fenfluramine in wildtype mice, but not in the $5-\mathrm{HT}_{1 \mathrm{~B}}$ knock-out mice. Our results thus demonstrate that stimulation of $5-\mathrm{HT}_{1 \mathrm{~B}}$ receptors is required for fenfluramine-induced anorexia and suggest a role for the PVN, CeA, and BNST in mediating this effect.

Key words: fenfluramine; feeding; serotonin $1 B$ receptor; knock-out mice; RU24969; Fos; paraventricular nucleus of the hypothalamus; central amygdaloid nucleus; bed nucleus of the stria terminalis

5- $\mathrm{HT}_{3}$, and $5-\mathrm{HT}_{4}$ receptors are unlikely (Neill and Cooper, 1989; Vickers et al., 1996). Attenuation of fenfluramine-induced hypophagia by the $5-\mathrm{HT}_{1 \mathrm{~A} / 1 \mathrm{~B}}$ antagonist cyanopindolol indicates that $5-\mathrm{HT}_{1 \mathrm{~B}}$ receptors may play a prominent role (Neill and Cooper, 1989; Grignaschi and Samanin, 1992; Grignaschi et al., 1995). Experiments performed on 5-HT-depleted animals indicate that $5-\mathrm{HT}_{2 \mathrm{C}}$ and yet unknown metergoline-sensitive receptors may also be critical (Gibson et al., 1993; Curzon et al., 1997).

Several studies suggest that fenfluramine exerts its effects by acting through the paraventricular nucleus of the hypothalamus (PVN) (Leibowitz, 1992). Microinjection of indirect 5-HT agonists fenfluramine and fluoxetine and $5-\mathrm{HT}_{1 \mathrm{~B}}$ direct agonists RU24969 and 1-[3-trifluoromethylphenyl]-piperazine into the PVN has been shown to elicit hypophagia (Hutson et al., 1988; Leibowitz et al., 1990; Weiss et al., 1990, 1991). Lesioning the PVN, however, does not alter the hypophagic response elicited from systemic administration of the compounds (Fletcher et al., 1993), indicating, therefore, that other hypothalamic nuclei and/or extrahypothalamic pathways may also contribute.

As an alternative to classic pharmacological approaches, mice lacking neurotransmitter receptors are useful tools for deciphering the specific receptors responsible for behavioral and physiological responses (Lucas and Hen, 1995). We have generated mice lacking the 5- $\mathrm{HT}_{1 \mathrm{~B}}$ receptor (Saudou et al., 1994) and have demonstrated the contribution of $5-\mathrm{HT}_{1 \mathrm{~B}}$ receptors in a variety of behaviors and physiological effects (Saudou et al., 1994; Crabbe et al., 1996; Ramboz et al., 1996; Yu et al., 1996; Brunner and Hen, 1997, Lucas et al., 1997; Rocha et al., 1998). In this paper, using a food intake behavior paradigm, we show that the hypophagic effect of fenfluramine is absent in $5-\mathrm{HT}_{1 \mathrm{~B}}$ knock-out mice, indi- 
cating that stimulation of $5 \mathrm{HT}_{1 \mathrm{~B}}$ receptors is required for this response.

Finally, to elucidate possible brain structures and pathways that contribute to the $5-\mathrm{HT}_{1 \mathrm{~B}}$-mediated effects of fenfluramine, we examined immunoreactivity for c-fos, an immediate early gene whose induction in response to given stimuli can be used to map neuronal activation (Sagar et al., 1989; Morgan and Curran, 1991). We show that fenfluramine elicits a reduced induction of c-fos in the PVN in knock-out animals, and that the central amygdaloid complex is a candidate extrahypothalamic brain region to mediate $5-\mathrm{HT}_{1 \mathrm{~B}^{-}}$and fenfluramine-induced anorexia.

\section{MATERIALS AND METHODS}

Animals. All experiments were performed on adult wild-type and 5- $\mathrm{HT}_{1 \mathrm{~B}}$ knock-out $129 / \mathrm{Sv}$-ter inbred mice. The $5-\mathrm{HT}_{1 \mathrm{~B}}$ knock-out mice were generated as described previously (Saudou et al., 1994). Both the wildtype and knock-out mice are bred at the New York State Psychiatric Institute animal facility and are identified by genomic Southern analyses of tail biopsies (Saudou et al., 1994). Mice were housed four per cage with food and water available ad libitum and maintained in a temperaturecontrolled environment on a $12 \mathrm{hr}$ light/dark cycle with light onset at 7:00 A.M. Immediately before testing, mice were housed individually, and water was maintained ad libitum.

Drug treatment. Fenfluramine hydrochloride [ $N$-ethyl-a-methyl- $m$-(trifluoromethyl)phenylethylamine; Sigma, St. Louis, MO] and RU24969 (generously supplied by Roussel-Uclaf, Romainville, France) were dissolved in $0.9 \% \mathrm{NaCl}$ solution. Drugs were administered intraperitoneally in volumes of $1.0 \mathrm{ml} / \mathrm{kg}$. Control animals were given an equivalent volume of the vehicle via the same route.

Feeding behavior paradigms. In all designs, food was given in pellet form and was provided in the food and water racks that are placed in each cage. The food form and the manner it was administered is the same for testing and for maintenance. Six to seven age-matched animals were used in each of the following groups: (1) for the baseline feeding response group, individually housed animals were given a preweighed quantity of chow, and the amount of food eaten was measured after $96 \mathrm{hr}$; and (2) for the feeding response to food deprivation group, mice were food-deprived, but not water-deprived, for $24 \mathrm{hr}$. Food was then readministered, and the amount of intake was measured after $20 \mathrm{~min}$ and 1 , 4 , and $24 \mathrm{hr}$. To determine the effect of drugs on feeding, an injection of drug (fenfluramine at 3 or $10 \mathrm{mg} / \mathrm{kg}$ or RU24969 at $5 \mathrm{mg} / \mathrm{kg}$ ) or vehicle was given after the deprivation period. The above protocol was repeated $5 \mathrm{~min}$ after the injection of fenfluramine or $20 \mathrm{~min}$ after RU24969.

Locomotion paradigm. Testing was conducted between 8:00 A.M. and 5:00 P.M. Animals were placed in $20 \times 20 \mathrm{~cm}$ open-field chambers. They were monitored throughout the test session by a video-tracking system (PolyTrack; San Diego Instruments, San Diego, CA) that records the animal's location and path. It monitors up to four animals simultaneously through a video camera located above the open field that records each animal's position every $0.5 \mathrm{sec}$. The system is also equipped with infrared photo beams located $4 \mathrm{~cm}$ above the floor of the open field that record rearing events. Similarly, there are eight photocell-equipped holes located around the perimeter of the field that record nose poke events. Animals are also videotaped throughout all test sessions.

To habituate animals to the injection procedure and the open field, on the day before testing began the mice were given saline injections intraperitoneally and then monitored in the open field for $30 \mathrm{~min}$. For drug testing, animals were brought to the testing room $1 \mathrm{hr}$ before the test session began. Animals were injected with either fenfluramine or saline vehicle $10 \mathrm{~min}$ before the test session. Then, animals were placed directly in the open field and monitored continuously for $90 \mathrm{~min}$. Data regarding each animal's path length, rearing, and nose poke behavior and the time spent in the center of the open field were collected and summed for each 5 min interval during the test session.

Immunohistochemistry. Mice were administered drugs intraperitoneally. Food was not available to the animals at this time, but water was maintained ad libitum. Two hours after drug administration, mice were anesthetized with a ketamine-Rompum mixture and perfused transcardially with $4 \%$ paraformaldehyde in $0.1 \mathrm{M}$ PBS for $10 \mathrm{~min}$. Brains were post-fixed in $4 \%$ paraformaldehyde for $2 \mathrm{hr}$ at room temperature and then stored in PBS with $30 \%$ sucrose for $48 \mathrm{hr}$ at $4^{\circ} \mathrm{C}$. Coronal sections $(30 \mu \mathrm{m})$ were cut on a freezing microtome and collected in PBS with $0.3 \%$ sodium azide. Free-floating sections were pretreated with $3 \% \mathrm{H}_{2} \mathrm{O}_{2}$ in PBS and incubated overnight at $4{ }^{\circ} \mathrm{C}$ in affinity-purified primary antibody raised against the c-fos N-peptide (AB-2; Oncogene Sciences, Mineola, NY) diluted 1:500 in PBS containing 0.3\% Triton X-100, 10\% normal goat serum (Life Technologies, Gaithersburg, MD), and 1\% BSA (Boehringer Mannheim, Indianapolis, IN). Sections were then rinsed and carried through standard avidin-biotin immunohistochemical protocols using an Elite Vectastain kit (Vector Laboratories, Burlingame, CA). Chromogen reaction was performed with 3,3-diaminobenzidine tetrahydrochloride (Sigma, St Louis, MO) and $0.003 \% \mathrm{H}_{2} \mathrm{O}_{2}$ for $10 \mathrm{~min}$. The sections were mounted on chromalum-coated slides and coverslipped with Aqua-PolyMount (Polysciences, Warrington, PA). Omission of the primary antibody or preabsorption with the N-peptide (Oncogene Sciences, Mineola, NY) resulted in absence of labeling.

Cell counting. Counting of the number of immunopositive nuclei was performed using a computerized image analysis system (MCID; Imaging Research) attached to a microscope (Diaplan; Leica, Nussloch, Germany). The counting was performed in a semiautomated manner with shading error acquired in a nonsample containing part of the preparation to correct for uneven distribution of light and form and shape factors suitable for the used magnification. Analysis was done on multiple sections per brain spanning each brain region examined.

Data analysis. Mean amount of food eaten after drug administration was compared using one- and two-way ANOVA with food eaten after 1 , 4 , and $24 \mathrm{hr}$ as a repeated measure. Post hoc comparisons were made using Scheffé analysis. Similarly, mean locomotion was analyzed by a one-way ANOVA using activity in each successive 5 min interval as a repeated measure. Mean c-Fos positive nuclei per brain were analyzed via an unpaired $t$ test. All calculations were done using the Statview 4.0 program (Abacus Concepts, Calabasas, CA).

\section{RESULTS}

\section{Mice lacking the $5-\mathrm{HT}_{1 \mathrm{~B}}$ receptor do not differ from wild-type mice in body weight or baseline food intake}

Body weight was compared between wild-type and knock-out mice at different ages (from early postnatal to 24 weeks). No significant difference was seen at any age. For example, at 20 weeks wild-type mice weighed $33.3 \pm 0.6 \mathrm{gm}(n=22)$, whereas the knock-out mice weighed $33.4 \pm 0.5 \mathrm{gm}(n=20)$. Next, the baseline feeding response of the two groups was monitored over a $96 \mathrm{hr}$ period in free-feeding, individually housed animals. Again, no significant difference was detected (Fig. 1A). Similarly, after a $24 \mathrm{hr}$ period of food deprivation, the amount of food intake after $20 \mathrm{~min}$ (data not shown) and 1, 4, and $24 \mathrm{hr}$ also indicated no detectable difference between wild-type and knockout animals (Fig. 1B).

\section{Mice lacking the 5- $\mathrm{HT}_{1 \mathrm{~B}}$ receptor display no hypophagia after fenfluramine administration}

The possible role of the $5-\mathrm{HT}_{1 \mathrm{~B}}$ receptors was explored by comparing the effect of fenfluramine in feeding behavior of wild-type and $5-\mathrm{HT}_{1 \mathrm{~B}}$ knock-out mice. After a $24 \mathrm{hr}$ food deprivation period, both groups were administered saline or a 3 or $10 \mathrm{mg} / \mathrm{kg}$ dose of fenfluramine. A preweighed quantity of pellets was made available 5 min after drug administration, and food intake was measured after 1, 4, and $24 \mathrm{hr}$. The response after fenfluramine administration differed between the two groups over time. ANOVA revealed a significant interaction between genotype and dose (Fig. 2). In agreement with previous findings (Shukla et al., 1990), a $10 \mathrm{mg} / \mathrm{kg}$ dose of fenfluramine significantly reduced food intake in wild-type animals when compared with saline at hours 1 and 4. An intermediate dose of $3 \mathrm{mg} / \mathrm{kg}$ was sufficient to induce this anorectic effect to a similar degree. In sharp contrast to the wild type, both 3 and $10 \mathrm{mg} / \mathrm{kg}$ fenfluramine failed to reduce food intake in the 5- $\mathrm{HT}_{1 \mathrm{~B}}$ knock-outs at all times studied. By hour 24, fenfluramine-treated wild-type animals ate similar amounts to control at both doses (data not shown). 
A
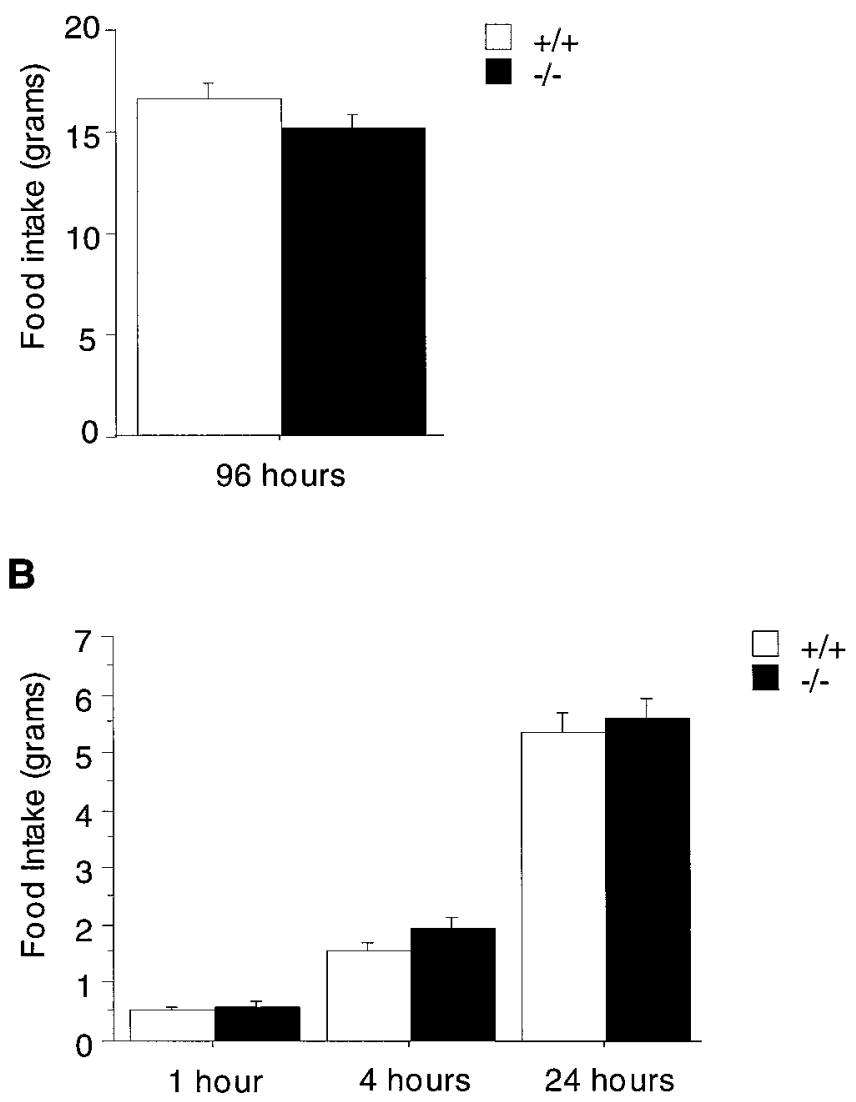

Figure 1. Mean \pm SEM food intake of wild types (white bars) and 5- $\mathrm{HT}_{1 \mathrm{~B}}$ knock-outs (black bars). $A$, Total baseline food consumption as monitored over a $96 \mathrm{hr}$ period. $B$, Response to $24 \mathrm{hr}$ of food deprivation. Amount of food intake was measured after 1, 4, and $24 \mathrm{hr}$ after the reintroduction of food. No significant effect of genotype was found.

The 5- $\mathrm{HT}_{1 \mathrm{~A} / 1 \mathrm{~B}}$ mixed agonist RU24969 fails to elicit a hypophagic response in $5-\mathrm{HT}_{1 \mathrm{~B}}$ knock-out mice

Food intake of food-deprived wild-type and knock-out mice after administration of $5 \mathrm{mg} / \mathrm{kg} \mathrm{5-HT}$ 1A/1B agonist RU24969 was determined (Fig. 3). A strong interaction between genotype and dose was again revealed via ANOVA. RU24969 caused a sharp decrease in food intake over a $4 \mathrm{hr}$ period in wild-type mice when compared with saline-injected counterparts. The 5- $\mathrm{HT}_{1 \mathrm{~B}}$ knockouts, however, showed no significant decrease in food intake in response to RU24969. The anorectic effect of RU24969 in wildtype mice and its absence in knock-out mice is in agreement with the reported ability of 5- $\mathrm{HT}_{1 \mathrm{~B}}$ agonists to decrease food intake in rats (Kennett et al., 1987; Kennett and Curzon, 1988; Lee and Simansky, 1997).

\section{Feeding response is independent of locomotor effect of fenfluramine}

5- $\mathrm{HT}_{1 \mathrm{~B}}$ agonists are known to increase locomotion (Oberlander et al., 1986; Cheetham and Heal, 1993). On the contrary, fenfluramine has been reported to decrease locomotion in rats (Callaway et al., 1993). We thus reasoned that a difference between wild-type and knock-out mice in baseline locomotor activity or in the effect of fenfluramine on locomotion might contribute to the difference found in the food intake paradigm. To address this, we compared the locomotor effect of fenfluramine in these mice. On the testing day, mice were given saline vehicle or 3 or $10 \mathrm{mg} / \mathrm{kg}$ fenfluramine intraperitoneally and monitored in an open field for $60 \mathrm{~min}$. Data were collected every $0.5 \mathrm{sec}$ and summed to $5 \mathrm{~min}$ intervals. As reported previously (Saudou et al., 1994), wild-type and knock-out mice did not differ in baseline locomotor behavior (Fig. 4). As in rats, fenfluramine decreased locomotion in mice in a dose-dependent manner. Importantly, the hypolocomotor effect in the $5-\mathrm{HT}_{1 \mathrm{~B}}$ knock-outs was indistinguishable from the wild type, thus demonstrating that the difference seen in feeding is not attributable to a drug-induced change in locomotion. Exploratory parameters, such as rearings and nose pokes, also revealed a dose-dependent decrease attributable to fenfluramine, and no significant difference was seen between genotypes (data not shown).

\section{Fenfluramine-induced Fos-like immunoreactivity in PVN requires $5-\mathrm{HT}_{1 \mathrm{~B}}$ receptor activation}

The PVN has been suggested to play a crucial role in 5-HTinduced anorexia. This is further supported by the reported ability of fenfluramine, as well as endogenous satiety inducers such as cholecystokinin and 2-buten-4-olide, to activate c-Fos in this brain region (Verbalis et al., 1991; Li and Rowland, 1993; Hisano et al., 1994). To test whether stimulation of $5-\mathrm{HT}_{1 \mathrm{~B}}$ receptors is required for this effect of fenfluramine, we compared the level of c-Fos immunoreactivity in the PVN after fenfluramine administration (Fig. 5).

Although administration of saline produces virtually no c-Fospositive signal in the PVN of both wild-type and 5- $\mathrm{HT}_{1 \mathrm{~B}}$ knockout animals (Fig. $5 A$ ), a $10 \mathrm{mg} / \mathrm{kg}$ injection of fenfluramine produces a robust c-Fos signal in the PVN of wild-type animals (Fig. $5 B$ ). The signal induced in the $5-\mathrm{HT}_{1 \mathrm{~B}}$ knock-outs, however, was markedly reduced (Fig. $5 C$ ).

We then tested whether stimulation of $5-\mathrm{HT}_{1 \mathrm{~B}}$ receptor with the direct agonist RU24969 would also be able to induce c-Fos in the PVN. A $5 \mathrm{mg} / \mathrm{kg}$ injection of RU24969 produced results similar to fenfluramine. In the wild-type mouse, RU24969 induced a robust signal in the PVN, whereas virtually no signal was present in the knock-out (Fig. 6). Because the induction is absent in the knock-out, it appears that RU24969 induces c-Fos through its $5-\mathrm{HT}_{1 \mathrm{~B}}$ agonist effect and not via activation of $5-\mathrm{HT}_{1 \mathrm{~A}}$ receptors.

\section{Central amygdaloid complex is a candidate brain region to mediate $5-\mathrm{HT}_{1 \mathrm{~B}}$ - and fenfluramine-induced anorectic effect}

In an attempt to identify extrahypothalamic regions that may contribute to the hypophagic effect of these compounds, we compared the Fos levels in brain regions in which fenfluramine has been shown to induce c-Fos. Among these structures are the central nucleus of the amygdala $(\mathrm{CeA})$, the bed nucleus of stria terminalis (BNST), the midline thalamic nuclei, and the striatum (Richard et al., 1992; Li and Rowland, 1993).

In agreement with previous findings in rats ( $\mathrm{Li}$ and Rowland 1993 ), a $10 \mathrm{mg} / \mathrm{kg}$ dose of fenfluramine induced c-fos in all of these brain regions in wild-type mice (Fig. 7) (data not shown). In contrast, virtually no induction was seen in the CeA and BNST of the knock-out mice (Fig. 7C,F), although the induction found in the midline thalamic nuclei and the striatum showed little, if any, difference (data not shown). These results suggest that the reduced induction in knock-out PVN, CeA, and BNST is specific and not attributable to abnormal pharmacokinetic properties of fenfluramine in the knock-out mice.

We then tested whether a $5 \mathrm{mg} / \mathrm{kg}$ dose of RU24969 would be 
Figure 2. Mean \pm SEM food intake of wild types (white bars) and $5-\mathrm{HT}_{1 \mathrm{~B}}$ knock-outs (black bars) 1 and $4 \mathrm{hr}$ after fenfluramine administration. Values on the $x$-axis indicate dose of fenfluramine $(\mathrm{mg} / \mathrm{kg})$. Drug was administered intraperitoneally after $24 \mathrm{hr}$ of food deprivation. At hour 1 , there was a main effect of genotype $\left(F_{(1,34)}=32.54 ; p<0.0001\right)$, a main effect of dose $\left(F_{234)}=15.30 ; p<0.001\right)$, and an interaction of genotype by dose $\left(F_{(2,34)}=3.46 ; p<0.05\right)$. At hour 4 , there was a main effect of genotype $\left(F_{(1,34)}=15.19\right.$; $p<0.001)$ and an interaction of genotype by dose $\left(F_{(2,34)}=\right.$ $3.51 ; p<0.05)$. Post hoc Scheffé analysis revealed that in wild types, fenfluramine significantly decreased food intake at both 3 and $10 \mathrm{mg} / \mathrm{kg}$ at hours 1 and $4.5-\mathrm{HT}_{1 \mathrm{~B}}$ knock-outs, however, did not demonstrate any significant change in feeding at either dose. Asterisks denote significant decreases in intake as compared with saline administration: ${ }^{*} p<0.01$; ${ }^{* *} p<0.005 ; * * * p<0.001$.

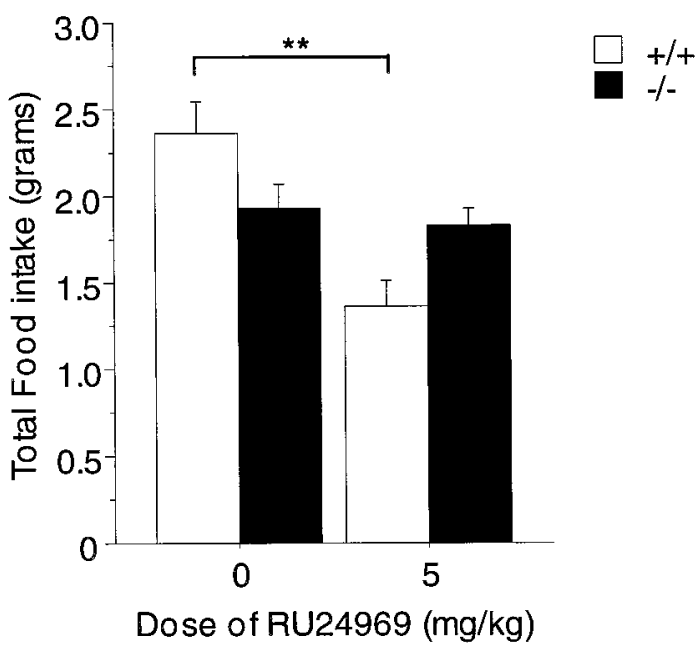

Figure 3. Mean \pm SEM food intake of wild types (white bars) and $5-\mathrm{HT}_{1 \mathrm{~B}}$ knock-outs (black bars) after injection of the $5-\mathrm{HT}_{1 \mathrm{~A} / 1 \mathrm{~B}}$ mixed agonist RU 24969. Injections were given intraperitoneally after a $24 \mathrm{hr}$ food deprivation period. ANOVA revealed an interaction of genotype by dose $\left(F_{(1,20)}=10.25 ; p<0.005\right)$. A $5 \mathrm{mg} / \mathrm{kg}$ dose of RU 24969 significantly reduced the amount of food intake in wild types $(* *<0.005)$, whereas the anorectic effect was absent in knock-outs. The saline-injected groups were not significantly different.

able to mimic the induction of c-Fos elicited by fenfluramine. RU24969 also induced c-Fos immunoreactivity in both the CeA and BNST of wild-type mice (data not shown). Again, this effect was absent in the knock-out mice, thus pointing to a mediation by $5-\mathrm{HT}_{1 \mathrm{~B}}$ receptors.

\section{DISCUSSION}

Using mice lacking the $5-\mathrm{HT}_{1 \mathrm{~B}}$ receptor, we show that fenfluramine does not induce hypophagia in these mice, thus indicating that activation of the $5-\mathrm{HT}_{1 \mathrm{~B}}$ receptor is necessary for this response. Furthermore, by examining the c-Fos induction in different brain regions, we find that there is robust induction in the PVN, the CeA, and BNST of wild type, whereas partial to no induction was found in the knock-outs. The CeA and BNST, therefore, are potential extrahypothalamic brain regions that may contribute to the effects of fenfluramine.

Our results indicating that $5-\mathrm{HT}_{1 \mathrm{~B}}$ receptors play an important role for the anorectic effect of fenfluramine do not contradict
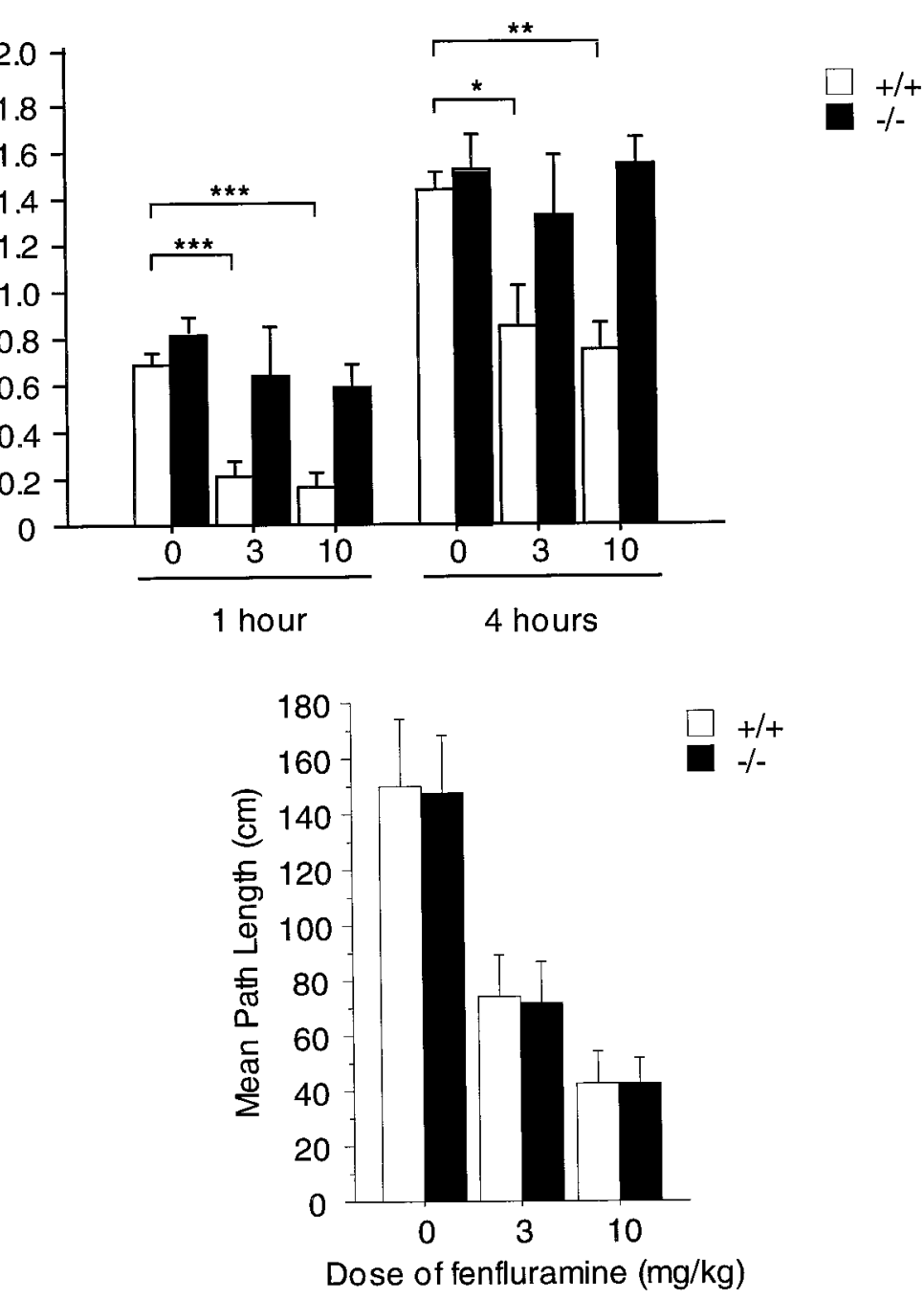

Figure 4. Mean \pm SEM path length traversed by wild types (white bars) and 5 - $\mathrm{HT}_{1 \mathrm{~B}}$ knock-outs (black bars) in 5 min intervals after intraperitoneal administration of 0,3 , or $10 \mathrm{mg} / \mathrm{kg}$ fenfluramine. Habituated animals were monitored for $1 \mathrm{hr}, 10 \mathrm{~min}$ after injection. Mean path length decreases in a dose-dependent manner after fenfluramine administration for wild types and 5-HT $\mathrm{H}_{1 \mathrm{~B}}$ knock-outs. ANOVA revealed a main effect of treatment $\left(F_{(2,696)}=21.51 ; p<0.0001\right)$, whereas there was no effect of genotype $\left(F_{(1,696)}=0.009 ; p=0.9262\right)$ and no interaction between genotype and treatment $\left(F_{(2,696)}=0.003 ; p=0.9967\right)$.

those suggesting that stimulation of $5-\mathrm{HT}_{2 \mathrm{C}}$ also contributes (for review, see Garattini et al., 1989; Dourish, 1992). Although there has been controversy as to whether stimulation of $5-\mathrm{HT}_{2 \mathrm{C}}$ reduces food intake or simply the rate of eating without affecting total food intake (for review, see Simansky, 1996), it is possible that simultaneous and synergistic activation of $5-\mathrm{HT}_{1 \mathrm{~B}}$ and $5-\mathrm{HT}_{2 \mathrm{C}}$ receptors are required to induce the full effect. The observation that $\mathrm{c}$-fos induction by fenfluramine in the PVN is reduced but not absent in the knock-out, concurrently with the reported ability of the 5- $\mathrm{HT}_{2 \mathrm{~A} / 2 \mathrm{C}}$ agonist 1-[2,5-dimethoxy-4-iodophenyl]2-aminopropane to induce Fos in the PVN (Rouillard et al., 1996), may reflect this synergism.

Recently, it has been hypothesized that the effect of fenfluramine might be attributable to direct activation of postsynaptic receptors while being independent of elevated synaptic 5-HT levels (Menini et al., 1991; Gibson et al., 1993; Curzon et al., 1997). This hypothesis arises from the observation that the hy- 

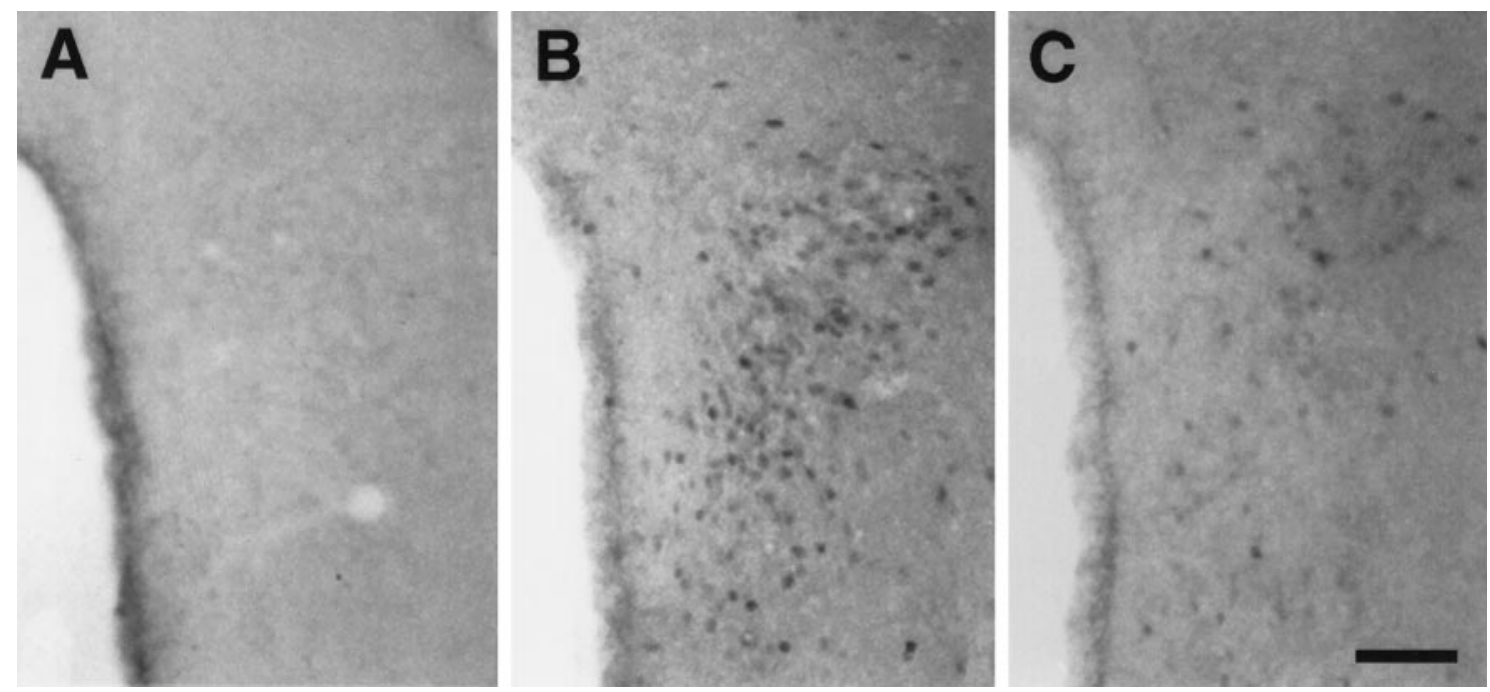

Figure 5. Induction of c-Fos in the PVN after administration of fenfluramine. $A$, Wild-type PVN after administration of saline. Wild-type and knock-out PVN after saline administration was indistinguishable. $B, \mathrm{~A} 10 \mathrm{mg} / \mathrm{kg}$ dose elicited a robust induction in wild types (128 $\pm 15 ; n=6$ brains), whereas a significantly reduced induction was seen in knock-outs $(38 \pm 4 ; n=6$ brains; $p<0.005)$ in $C$. Scale bar, $100 \mu \mathrm{m}$.
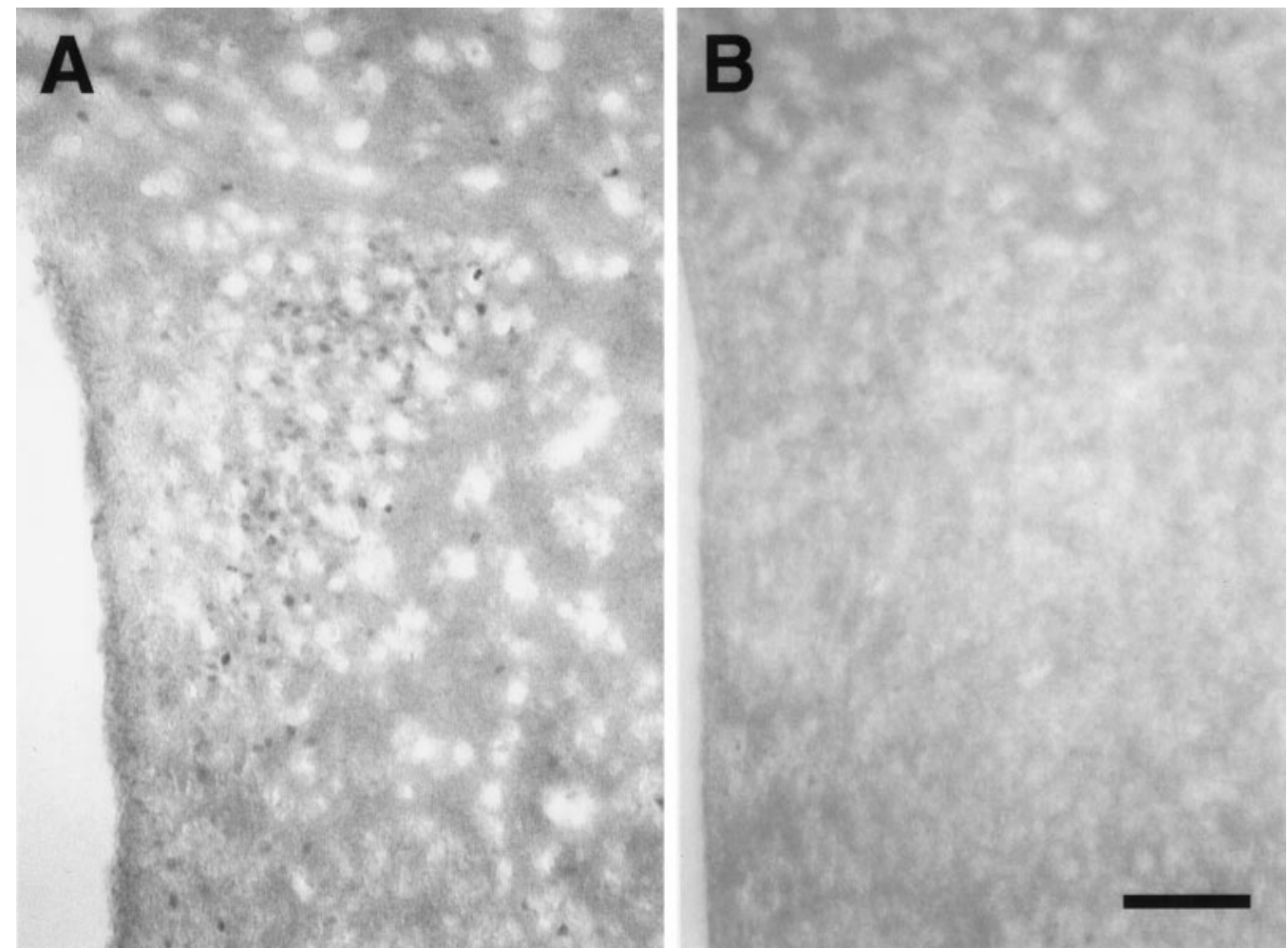

Figure 6. Induction of $\mathrm{c}-\mathrm{Fos}$ in the $\mathrm{PVN}$ by the 5- $\mathrm{HT}_{1 \mathrm{~A} / 1 \mathrm{~B}}$ direct agonist RU 24969. $A$, Wild-type PVN demonstrated a strong c-Fos induction after administration of $5 \mathrm{mg} / \mathrm{kg}$ RU 24969 intraperitoneally $(94 \pm 9 ; n=6$ brains). $B$, In knock-out PVN, however, no c-Fos-positive nuclei were seen ( $n=$ 6 brains). Scale bar, $100 \mu \mathrm{m}$.

pophagic effect of $d$-fenfluramine was not significantly affected by pretreatment with the inhibitor of 5-HT synthesis $p$-chlorophenylalanine ( $p$-CPA) (Gibson et al., 1993). However, the lack of an effect by $p$-CPA may be explained by $d$-fenfluramine acting on $p$-CPA-resistant nerve terminals. In addition, a direct effect of fenfluramine on $5 \mathrm{HT}_{1 \mathrm{~B}}$ receptors is unlikely, because fenfluramine and its metabolites display very low affinity for 5- $\mathrm{HT}_{1 \mathrm{~B}}$ receptor sites (Menini et al., 1991). Therefore, our findings, as well as the previously reported ability of cyanopindolol, a $5 \mathrm{HT}_{1 \mathrm{~B}}$ antagonist, to antagonize fenfluramineinduced hypophagia (Neill and Cooper, 1989; Grignaschi and Samanin, 1992; Grignaschi et al., 1995), cannot be explained in terms of direct activation of a postsynaptic receptor.

We have shown that activation of $5-\mathrm{HT}_{1 \mathrm{~B}}$ receptors either by the direct agonist RU24969 or the indirect agonist fenfluramine results in reduced food intake. One may therefore expect that disruption of the gene encoding the $5-\mathrm{HT}_{1 \mathrm{~B}}$ receptor would result in an abnormal control of appetite, and therefore, abnormal body 
$\mathrm{WT}+\mathrm{sal}$
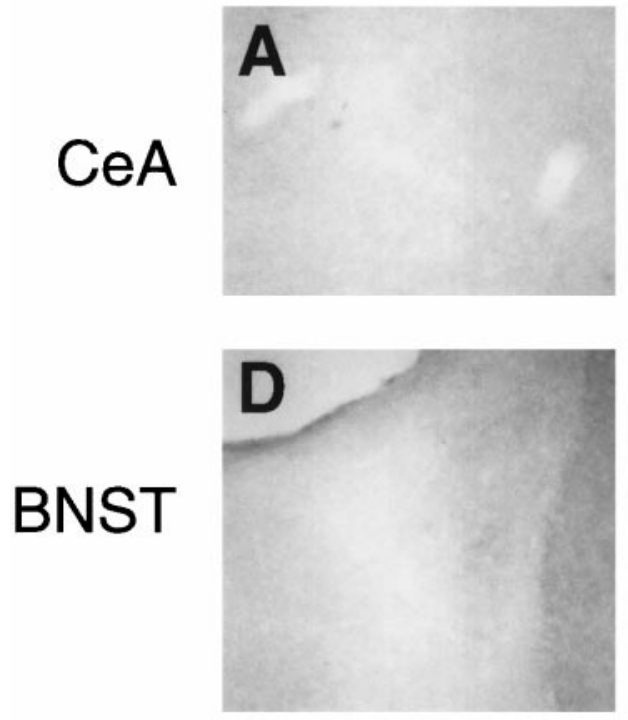

WT + fen
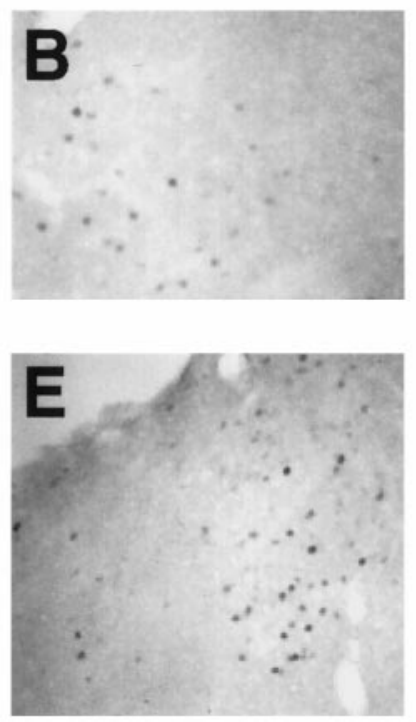

$\mathrm{KO}+$ fen
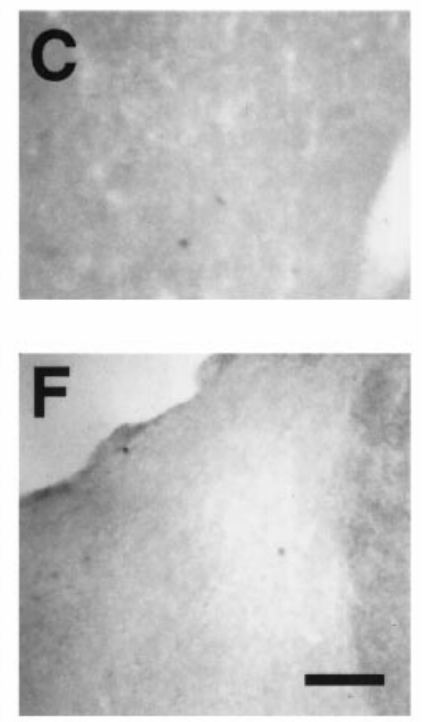

Figure 7. c-Fos induction in CeA and BNST by fenfluramine. Saline administration yielded no induction in either structure in wild type $(A, D)$. In response to fenfluramine, positively stained nuclei were seen in the CeA and BNST of wild types only $(B, E)$ and were absent in knock-outs $(C, F)$. Wild types and knock-outs were indistinguishable after saline administration. Scale bar, $1 \mathrm{~mm}$.

weight. The 5-HT $1 \mathrm{~B}$ knock-out mice, however, are indistinguishable from their wild-type littermates in body weight and total food intake over the test period. It is possible that compensations of other neurotransmitters and receptors involved in appetite control may have taken place to adjust for the absence of the $5-\mathrm{HT}_{1 \mathrm{~B}}$ receptor. An alternative explanation for the absence of a body weight phenotype is that $5-\mathrm{HT}_{1 \mathrm{~B}}$ receptors are not involved in the regulation of baseline feeding behavior. This may explain why attempts to antagonize the $5-\mathrm{HT}_{1 \mathrm{~B}}$ receptors by classic pharmacological means do little to this behavior (Blundell and Latham, 1980; Lee and Clifton, 1992).

High densities of $5-\mathrm{HT}_{1 \mathrm{~B}}$ receptor binding sites have been reported in the $\mathrm{PVN}$ and $\mathrm{CeA}$, whereas moderate levels have been reported in the BNST (Bruinvels et al., 1994). Furthermore, these three brain regions receive a dense serotonergic innervation from raphe nuclei (Sawchenko et al., 1983; Ma et al., 1991; Alheid et al., 1995). The c-Fos induction found in these regions can therefore be a direct consequence of activation of $5-\mathrm{HT}_{1 \mathrm{~B}}$ receptors located there. It cannot be ruled out, however, that stimulation of $5-\mathrm{HT}_{1 \mathrm{~B}}$ receptors in other brain regions triggers this induction through a polysynaptic mechanism. In fact, substantia nigra, the brain region with the highest level of $5-\mathrm{HT}_{1 \mathrm{~B}}$ receptor sites, sends projections to both the CeA and the BNST (Alheid et al., 1995).

$5-\mathrm{HT}_{1 \mathrm{~B}}$ receptors are localized on axon terminals (Waeber and Palacios, 1989; Boschert et al., 1993; Bruinvels et al., 1993; Stark et al., 1997), where they have been shown to inhibit neurotransmitter release (Hoyer and Middlemiss, 1989; Johnson et al., 1992; Cameron and Williams, 1994; Hoyer et al., 1994). We do not know the mechanisms through which stimulation of $5-\mathrm{HT}_{1 \mathrm{~B}}$ receptors located within and/or outside the PVN, CeA, and BNST results in induction of c-Fos. For the PVN, it is possible to speculate about potential mechanisms because its interconnections are relatively well known. The assumption that local $5-\mathrm{HT}_{1 \mathrm{~B}}$ receptors are involved is based on the observation that local application of 5-HT 1 B agonists elicits hypophagia (Hutson et al.,
1988). The arcuate nucleus (ARC), the main source of neuropeptide Y containing afferents to the PVN (Morris, 1989), contains one of the highest densities of $5-\mathrm{HT}_{1 \mathrm{~B}}$ receptor mRNA in the brain (Bruinvels et al., 1994). It is therefore likely that at least a fraction of the $5-\mathrm{HT}_{1 \mathrm{~B}}$ receptors in the PVN are located on NPYergic terminals emanating from the ARC. It is likely that stimulation of $5 \mathrm{HT}_{1 \mathrm{~B}}$ receptors located on these terminals will inhibit NPY release. Because NPY is a potent feeding inducer, a decrease in NPY levels as a consequence of $5-\mathrm{HT}_{1 \mathrm{~B}}$ receptor stimulation might account, at least in part, for the $5-\mathrm{HT}_{1 \mathrm{~B}}$-related effects of fenfluramine reported here.

Unlike the PVN, however, the role of the central amygdaloid complex in feeding behavior and energy balance has not been fully explored. The central amygdaloid group includes the $\mathrm{CeA}$ and elements of the BNST (Alheid et al., 1995). Moderate levels of $5 \mathrm{HT}_{1 \mathrm{~B}}$ receptor mRNA have been found in this region (Bruinvels et al., 1994). Interestingly, this region has been implicated in learned taste aversion (Borsini and Rolls, 1984), and studies also indicate that this structure is involved in the control of food intake and energy balance (Weingarten et al., 1985; Kyrouli et al., 1990; Wyrwicka, 1992). In fact, one of the most characteristic anatomical features of this structure is its reciprocal connections with the brainstem, namely the parabrachial area (de Olmos 1969, 1972; Schwaber et al., 1982; Alheid et al., 1995). The parabrachial area has been implicated in ingestive behavior as well (Takaki et al., 1990, Wyrwicka 1992). The 5-HT ${ }_{1 \mathrm{~B}}$ receptor mRNA found in the central amygdaloid complex may be in neurons projecting to the parabrachial area, which express the $5-\mathrm{HT}_{1 \mathrm{~B}}$ receptor protein (Bruinvels et al., 1994). Via this innervation, ingestive behavior may be modulated.

In summary, by studying the effects of fenfluramine in $5-\mathrm{HT}_{1 \mathrm{~B}}$ knock-out mice, we have found that stimulation of this receptor is required for the anorectic action of this drug. We have also found that $5-\mathrm{HT}_{1 \mathrm{~B}}$ receptor stimulation is required for induction of c-fos in the PVN, CeA, and BNST, therefore suggesting a role of these regions in mediating fenfluramine-induced anorexia. Fi- 
nally, we have shown that stimulation of $5-\mathrm{HT}_{1 \mathrm{~B}}$ receptors in wild-type mice with the direct agonist RU24969 is able to mimic both the anorectic and c-fos effects of fenfluramine. These results imply that $5-\mathrm{HT}_{1 \mathrm{~B}}$ agonists might be a therapeutic alternative to fenfluramine for the treatment of obesity. Importantly, this treatment may avoid the complications of pulmonary hypertension and mitral valve insufficiency that is seen with this general serotonin releaser and uptake inhibitor (Newman, 1997; Deitel, 1997). With the recent surge in the development of $5-\mathrm{HT}_{1 \mathrm{~B}}$-specific agonists for their anti-migraine properties (Schoenen, 1997), this viable alternative may soon be within our reach.

\section{REFERENCES}

Alheid GF, de Olmos JS, Beltramino CA (1995) Amygdala and extended amygdala. In: The rat nervous system, Ed 2 (Paxinos G, ed), pp 495-500. London: Academic.

Blundell JE, Latham CJ (1980) Characterization of adjustments to the structure of feeding behavior following pharmacological treatment: effects of amphetamine and fenfluramine and the antagonism produced by pimozide and methergoline. Pharmacol Biochem Behav 12:717-722.

Borsini F, Rolls ET (1984) Role of adrenaline in the basolateral region of the amygdala in food preferences and learned tasted aversion in rats. Int J Obes 11:141-155.

Boschert U, Ait Amara D, Segu L, Hen R (1993) The mouse 5-hydroxytryptamine $1 \mathrm{~B}$ receptor is localized predominantly on axon terminals. Neuroscience 58:167-182.

Bruinvels AT, Palacios JM, Hoyer D (1993) Autoradiographic characterization and localisation of $5-\mathrm{HT}_{1 \mathrm{D}}$ compared to $5-\mathrm{HT}_{1 \mathrm{~B}}$ binding sites in the rat brain. Naunyn-Schmiedebergs Arch Pharmakol 347:569-582.

Bruinvels AT, Brancheck TA, Landwehrmeyer B, Mengod G, Hoyer D, Palacios JM (1994) Localisation of 5-HT1B, 5-HT1Da, 5-HT1E, and 5 -HT1F receptor messenger RNA in rodent and primate brain. Neuropharmacology 33:367-386.

Brunner D, Hen R (1997) Insights in neurobiology of impulsive behavior from serotonin knockout mice. In: The neurobiology of suicide: from the bench to the clinic (Stoff DM, Mann JJ, eds), pp 81-105. New York: New York Academy of Sciences.

Callaway CW, Wing LL, Nichols DE, Geyer MA (1993) Suppression of behavioral activity by norfenfluramine and related drugs in rats is not mediated by serotonin release. Psychopharmacology 111:169-178.

Cameron DL, Williams JT (1994) Cocaine inhibits GABA release in the VTA through endogenous 5-HT. J Neurosci 14:6733-6767.

Cheetham SC, Heal DJ (1993) Evidence that RU24969-induced locomotor activity in C57/B1/6 mice is specifically mediated by the 5-HT1B receptor. Br J Pharmacol 110:1621-1629.

Crabbe J, Phillips T, Feller D, Hen R, Wenger C, Lessov C, Schafer G (1996) Elevated alcohol consumption in null knockout mice lacking 5-HT1B receptors. Nat Genet 13:98-101.

Curzon G, Gibson EL, Oluyomi AO (1997) Appetite suppression by commonly used drugs depends on 5-HT receptors but not on 5-HT availability. Trends Pharmacol Sci 18:21-25.

Davis R, Faulds D (1996) Dexfenfluramine. An updated review of its therapeutic use in the management of obesity. Drugs 52:696-724.

de Olmos JS (1969) A cupric-silver method for the impregnation of terminal axon degeneration and its further use in staining granular agryphilic neurons. Brain Behav Evol 2:213-237.

de Olmos JS (1972) The amygdaloid projection field in the rat as studied with the cupric-silver staining method. In: The neurobiology of the amygdala (Eleftheriou BE, ed), pp 145-204. New York: Plenum.

Dietel M (1997) Debate over dexfenfluramine. Can Med Assoc J 157:14.

Dourish CT (1992) 5-HT and ingestive behavior. In: Central serotonin receptors and psychotropic drugs (Marden CA, Heal DJ, eds), pp 260-291. London: Blackwell Scientific.

Fletcher PJ, Currie PJ, Chambers JW, Coscina, DV (1993) Radiofrequency lesions of the PVN fail to modify the effects of serotonergic drugs on food intake. Brain Res 630:1-9.

Garattini S, Mennini T, Samanin R (1989) Central serotonergic mechanisms and feeding regulation. In: Neurochemical pharmacology: a tribute to B. B. Brodle (Costa E, ed), pp 89-106. New York: Raven.

Garrow J (1991) Importance of obesity. Br Med J 303:704-706.

Gibson EL, Kennedy AJ, Curzon G (1993) D-fenfluramine and
D-norfenfluramine-induced hypophagia: differential mechanisms and involvement of postsynaptic 5-HT receptors. Eur J Pharmacol 242:83-90.

Grignaschi G, Samanin R (1992) Role of 5-HT receptors in the effect of d-fenfluramine on feeding patterns in the rat. Eur J Pharmacol 212:287-289.

Grignaschi G, Sironi F, Samanin R (1995) The 5-HT1B receptor mediates the effect of d-fenfluramine on eating caused by intra-hypothalamic injection of neuropeptide Y. Eur J Pharmacol 274:221-224.

Guy-Grand B (1995) Clinical studies with dexfenfluramine: from past to future. Obes Res [Suppl] 4:491S-496S.

Hisano S, Uemura N, Fukui Y, Miki M, Zhang R (1994) Induction of Fos-like immunoreactivity in the rat hypothalamus by an endogenous feeding suppressant (2-buten-4-olide). Neurosci Lett 182:80-82.

Hoyer D, Middlemiss DN (1989) Species differences in the pharmacology of terminal 5-HT autoreceptors in mammalian brain. Trends Pharmacol Sci 10:130-132.

Hoyer D, Clarke DE, Fozard JR, Hartig PR, Martin GR, Mylecharane EJ, Saxena PR, Humphrey PP (1994) International union of pharmacology classification of receptors for 5-hydroxytryptamine (serotonin). Pharmacol Rev 46:157-203.

Hutson PH, Donohow TP, Curzon G (1988) Infusion of the 5-hydrozytryptamine agonists RU24969 and TFMPP into the paraventricular nucleus the hypothalamus causes hypophagia. Psychopharmacology 95:550-552.

Johnson SW, Mercuri NB, North RA (1992) 5-hydroxytryptamine 1B receptors block the GABAB synaptic potential in rat dopamine neurons. J Neurosci 12:2000-2006.

Kennett GA, Curzon G (1988) Evidence that hypophagia induced by $\mathrm{mCPP}$ and TFMPP requires 5-HT1C and 5-HT1B receptors; hypophagia induced by RU24969 requires only 5-HT1B receptors. Psychopharmacology 96:93-100.

Kennett GA, Dourish CT, Curzon G (1987) 5-HT1B agonists induce anorexia at a postsynaptic site. Eur J Pharmacol 141:429-435.

Kuczmarski RJ, Flegal KM, Campbell SM, Johnson CL (1994) Increasing prevalence of overweight among US adults. The national health and nutrition examination surveys, 1960 to 1991. J Am Med Assoc 272:205-211.

Kyrouli SE, Stanley BG, Seirafi RD, Leibowitz SF (1990) Stimulation of feeding by galanin-anatomical localization and behavioral specificity of this peptide effect in the brain. Peptides 11:995-1001.

Lee MD, Clifton PG (1992) Partial reversal of fluoxetine anorexia by the 5-HT antagonist metergoline. Psychopharmacology 107:359-364.

Lee MD, Simansky KJ (1997) CP-94,253: A selective serotonin 1B (5HT1B) agonist that promotes satiety. Psychopharmacology 131:264-270.

Leibowitz SF (1992) Neurochemical-neuroendocrine systems in the brain controlling macronutrient intake and metabolism. Trends Neurosci 15:491-497.

Leibowitz SF, Weiss GF, Suh JS (1990) Medial hypothalamic nuclei mediate serotonin's inhibitory effect on feeding behavior. Pharmacol Biochem Behav 37:735-742.

Li B-H, Rowland NE (1993) Dexfenfluramine induces Fos-like immunoreactivity in discrete brain regions in rats. Brain Res Bull 31:43-48.

Lucas JJ, Hen R (1995) New players in the 5-HT receptor field: genes and knockouts. Trends Pharmacol Sci 16:246-252.

Lucas JJ, Segu L, Hen R (1997) 5-HT1B receptors modulate the effect of cocaine on c-fos expression: converging evidence using 5-HT1B knockout mice and the 5-HT1B/1D antagonist GR127935. Mol Pharmacol 51:755-763.

Ma QP, Yin GF, Ai MK, Han HS (1991) Serotoninergic projections from the nucleus raphe dorsalis to the amygdala in the rat. Neurosci Lett 134:21-24.

Menini T, Bizzi A, Caccia S, Codegoni A, Fracasso C, Fritolli E, Guiso G, Padura IM, Taddei C, Uslenghi A, Garattini S (1991) Comparative studies on the anorectic activity of $d$-fenfluramine in mice, rats, and guinea pigs. Naunyn-Schmiedelbergs Arch Pharmakol 343:483-490.

Morgan JI, Curran T (1991) Stimulus-transcription coupling in the nervous system: involvement of the inducible proto-oncogenes fos and jun. Annu Rev Neurosci 14:421-451.

Morris BJ (1989) Neuronal localization of neuropeptide Y gene expression in rat brain. J Comp Neurol 290:358-368.

Neill JC, Cooper SJ (1989) Evidence that d-fenfluramine anorexia is mediated by 5-HT1 receptors. Psychopharmacology 97:213-218. 
Newman R (1997) Mitral valve disease associated with use of anorexigenic medications. Ann Thorac Surg 64:294.

Oberlander C, Blaquiere B, Pujol JF (1986) Distinct functions for dopamine and serotonin in locomotor behavior: evidence using the 5-HT1 agonist RU 24969 in globus pallidus-lesioned rats. Neurosci Lett 67:113-118.

Ramboz S, Saudou F, Aït Amara D, Belzung C, Misslin F, Segu L, Buhot M-C, Hen R (1996) 5-HT1B receptor knockout: physiological and behavioral consequences. Behav Brain Res 73:305-312.

Richard D, Rivest S, Rivier C (1992) The 5-hydroxytryptamine agonist fenfluramine increases Fos-like immunoreactivity in the brain. Brain Res 594:131-137.

Rocha BA, Scearce-Levie K, Lucas JJ, Hiroi N, Castanon N, Chen J, Gardner EL, Crabbe JC, Nestler EJ, Hen R (1998) Increased vulnerability to cocaine in mice lacking the serotonin-1B receptor. Nature 393:175-178.

Rouillard C, Bovetto S, Gervais J, Richard D (1996) Fenfluramineinduced activation of the immediate early gene c-fos in the striatum: possible interaction between serotonin and dopamine. Mol Brain Res 37:105-115.

Sagar SM, Sharp FR, Curran T (1989) Expression of c-fos protein in brain: metabolic mapping at the cellular level. Science 240:1328-1331.

Saudou F, Aït Amara D, LeMeur M, Ramboz S, Segu L, Buhot M, Hen R (1994) Enhanced aggressive behavior in mice lacking 5-HT1B receptor. Science 265:1875-1878.

Sawchenko PE, Swanson LW, Steinbusch HWM, Verhofstad AAJ (1983) The distribution and cells of origin of serotonergic inputs to the paraventricular and supraoptic nuclei of the rat. Brain Res 277:355-360.

Schoenen J (1997) Acute migraine therapy: the newer drugs. Curr Opin Neurol 10:237-243.

Schwaber JS, Kapp BS, Higgins GA, Rapp PR (1982) Amygdaloid and basal forebrain direct connections with the nucleus of solitary tract and the dorsal motor nucleus. J Neurosci 2:1424-1438.

Shukla R, MacKenzie-Taylor D, Rech RH (1990) Evidence for 5-HT2 receptor mediation in quipazine anorexia. Psychopharmacology 100:115-118.
Silverstone T (1992) Appetite suppressants. A review. Drugs 43:820-836. Simansky KJ (1996) Serotonergic control of the organization of feeding and satiety. Behav Brain Res 73:37-42.

Stark KL, Ghavami A, Segu L, Mayford M, Kandel E, Hen R (1997) Inducible knockout and tissue-specific rescue of the 5-HT1B receptor. Soc Neurosci Abstr 23:116.

Takaki A, Nagai K, Takaki S (1990) Satiety function of neurons containing a CCK-like substance in the dorsal parabrachial nucleus. Physiol Behav 48:865-871.

Verbalis JG, Stricker EM, Robinson AG, Hoffman GE (1991) Cholecystokinin activates c-fos in hypothalamic oxytocin and corticotropinreleasing hormone neurons. J Neuroendocrinol 3:205-213.

Vickers SP, Clifton PG, Dourish CT (1996) Behavioral evidence that d-fenfluramine-induced anorexia in the rat is not mediated by the 5HT-1A receptor subtype. Psychopharmacology 125:168-175.

Waeber C, Palacios JM (1989) Serotonin-1 receptor binding sites in the human basal ganglia are decreased in Huntington's chorea but not in Parkinson's disease: a quantitative in vitro autoradiography study. Neuroscience 32:337-347.

Weingarten HP, Chang P, McDonald TJ (1985) Comparison of the metabolic and behavioral disturbances following paraventricular- and ventromedial-hypothalamic lesions. Brain Res Bull 14:551-559.

Weiss GF, Rogacki N, Fueg A, Buchen D, Leibowitz SF (1990) Impact of hypothalamic D-norfenfluramine and peripheral D-fenfluramine injection on macronutrient intake in the rat. Brain Res Bull 25:849-859.

Weiss GF, Rogacki N, Fueg A, Suh JS, Wong DT, Leibowitz SF (1991) Effect of hypothalamic and peripheral fluoxetine injection on natural patterns of macronutrient intake in the rat. Psychopharmacology 105:467-476.

Wyrwicka W (1992) Brain and feeding behavior. Springfield, Il: Thomas.

Yu X-J, Waeber C, Castanon N, Scearce K, Hen R, Macor J, Moskowitz M (1996) Knockout mice lacking 5-HT1B receptors: 5-carboxamidotryptamine, CP-122,288 and dihydroergotamine, but not sumatriptan, CP-93,129 or serotonin-5-O-carboxymethyl-glycyl-tyrosinamide block dural plasma protein extravastion. Mol Pharmacol 49:761-765. 